\title{
Prevalence Rate of Urinary Schistosomiasis in Bali Town, Bali, Local Government Area, Taraba State, Nigeria
}

\author{
*11 Cletus Anes UKWUBILE, ${ }^{1}$ Timothy TILE \\ ${ }^{1}$ Department of Science Laboratory Technology Federal Polytechnic Bali, Nigeria \\ *doccletus@yahoo.com
}

\begin{abstract}
:
Introduction: Schistosomiasis is also known as Bilharzias which is a parasitic disease that leads to chronic ill health indicated among other symptoms of blood in the urine .

Objective: This was carried out in order to know the level of distribution of schistosomiasis in Bali Nigeria.

Methods: Field survey was carried out in Daniya, Sabon-layi and Kwararrafa areas in Bali town, Bali local Government Area, Taraba State, to assess the town water contact pattern influencing the epidemiology of urinary schistosomiasis. Eighty (80) urine samples were collected from the population randomly in the selected areas. The urine samples were analyzed using sedimentation method.
\end{abstract}

Results: 26 (32.5\%) of the population had S. haematobium ova in their urine. Swimming, washing and fishing accounted for $15 \%$ of the total water contact. The infection rate was higher in females (17.5\%) than in male (15\%) though not significant $(P \leq 0.05 ;$ ANOVA). Most of the activities took place in the morning hours (7:00 11:00 am), so the samples were collected within this time. Individuals within the ages of $5-11$ years have the highest infection rate (55\%). Highest prevalence rate in terms of areas was Daniya, while Sabon-layi, and Kwararrafa areas were the least.

Conclusion: Human- water contact activities that were observed in these areas favoured the endemicity of schistosomiasis. The study showed that urinary schistosomiasis is meso-endemic in Bali town among the population investigated.

Keywords: Schistosomiasis, S. haematobium, infection rate, water contact, meso-endemic.

\section{INTRODUCTION}

The blood fluke Schistosoma haematobium (Schistosomatoidea) is one of the major parasites infecting people in the world, causing a disease known as Schistosomiasis. It is a digenetic trematodes found in Middle East, India, Africa, etc. Schistosomiasis is also known as Bilharzias which is a parasitic disease that leads to chronic ill health indicated among other symptoms of blood in the urine[1].

Irrigation farming, fresh water fishing activities, walking in contaminated water bare footed, bathing, drinking and also swimming in contaminated water are all important predisposing factor [2]. All these can be as a result of extreme poverty, unawareness of the risk, inadequacy or total lack of public health facilities as well as unsanitary condition of the people in the rural area [2].

Available research record showed that, people in rural of an extensive irrigation area may be infected with the disease as a result of poor sanitation since the parasite is distributed by man in urine. The intermediate host is aquatic snail which is involved by ciliated larva (miracidium). This multiplies within the snail and infected larvae; cercariae finally, emerge to swim in the water. The cercariae penetrates through the skin of man to establish new infection [3].

Bali local government was created in 1976 during the local reform under the defunct Gongola state. There are two districts that make up Bali Local Government Area, namely; Dakka District, and Bakundi District. The local government headquarter is in Bali town. The area lies between latitude $5.54^{\circ} \mathrm{N}$ of the equator and longitude $10.0^{\circ} \mathrm{E}$ of the prime median. It is found in derived guinea savanna[4]. It is the largest local government in Taraba State, with an estimated land area of 11,540 $\mathrm{km}^{2}$, it has some mountains like Gazabu, Kamajin, Dakka, Maihula, Isaac, Bagoni, among others. Major rivers in the area include; River Taraba, Gazabu, Suntai and many streams surrounding the local government area. 
According to the National Population Census (NPC) 2006, the population of Bali local government was 208,935 persons. It has a tropical climate marked by two seasons; dry and rainy seasons. The rainy season starts around April and ends in November occasionally, with $1350-1500 \mathrm{~mm}$ rainfall annually. The local government is bordered with Ardo-kola, Gassol, Gashaka, and Donga local government areas. The major ethnic groups in the area include; Hausa, Tiv, Jibawa, Chamba, Fulani, Itchen etc. Farming, fishing, nomadism is the main occupation of the inhabitants [5].

This study was carried out in order to determine the prevalence of schistosomiasis in Bali town, Bali Local Government Area, Taraba State, Nigeria, determine the rate of infection in different sexes of humans in Bali, and infection rate in selected areas of Bali town.

\section{Materials AND Methods}

The following apparatus and materials were used to achieve the set objectives: Microscope (Light), Centrifuge (model 800, made in China), Sample Bottles, Microscope Slides, Cover Slips, Hand Glove, Pasture, Pipette, etc.

The study was conducted between September and October 2013, in the area of Daniya, Sabon-layi, and Kwararrafa in Bali town the Headquarters of Bali local government which is located $124 \mathrm{~km}^{2}$ South-east of Taraba State Headquarters (Jalingo); With a total population of 2,850 of which 1,400 were male and 1,450 were females [6].

2,850 individuals who live in Bali town were the sample size, 80 of them 5 years above were included in the study, in the areas of Daniya, Sabon-layi and Kwararrafa.

Data collection was done with respect to socio-demographic data which includes sex, age, religion, occupation and other necessary information.

\section{SAMPle Collection ANd Analysis}

Prior consent of the study as well as parents, relatives or guardians was sought for before urine samples were collected. The urine samples were collected from individuals age ( 5 and above) in $5 \mathrm{ml}$ sterile plastic sample bottles, fitted with screw cap.

After the samples were transferred to the laboratory having collected them using centrifuge tube. Six centrifuge test-tubes were placed firmly in the centrifuging machine (made in China, model 800) for the sedimentation of urine. Each of the centrifuging test-tubes was plugged with a cotton wool to avoid spillage while spinning. The samples were centrifuge at 4,000 rpm for 5 minutes.

Then samples were removed from the centrifuge, the supernatant was decanted in a sink and the deposits were microscopically examined. One drop of the deposit was placed on a microscope slide by the use of pasture pipette. Microscopic examination was carried out according to the method described by [7]. It was observed under 10x objective and 40x objective lens for confirmation of the eggs of the parasites using a light microscope (Olympus) for the presence of characterized eggs of $S$. haematobium.

\section{Statistical Analysis}

The raw data obtained were subjected to statistical analysis using student's t-test. Values of $\mathrm{P} \leq 0.05$ are described as being statistically significant using one-way ANOVA.

\section{RESUltS}

The following results were obtained from the experiment, and were represented in the tables below:

Table1. Distribution of Schistosoma Haematobium among Different Age Groups

\begin{tabular}{|l|l|l|l|}
\hline Age Group & № Of Sample Collected & № Of Infected (\%) & № Of Uninfected (\%) \\
\hline $5-10$ & 35 & 12 & 23 \\
\hline $11-15$ & 18 & 7 & 11 \\
\hline $16-20$ & 15 & 4 & 11 \\
\hline $21-25$ & 12 & 3 & 9 \\
\hline Total & $\mathbf{8 0}$ & $\mathbf{2 6}(\mathbf{3 2 . 5})$ & $\mathbf{5 4}(\mathbf{6 7 . 5 )}$ \\
\hline
\end{tabular}

*Results are means of original data expressed as percentage. Ages 5-10 were mostly infected in the table above. However, the older ones were least infected (table 1). 
Prevalence Rate of Urinary Schistosomiasis in Bali Town, Bali, Local Government Area, Taraba State, Nigeria

Table2. Distribution of Schistosoma Haematobium among Different Sexes

\begin{tabular}{|l|l|l|l|}
\hline Sex & Number Collected & Number Infected (\%) & Number Uninfected (\%) \\
\hline Male & 36 & 12 & 25 \\
\hline Female & 44 & 14 & 29 \\
\hline Total & $\mathbf{8 0}$ & $\mathbf{2 6}(\mathbf{3 2 . 5})$ & $\mathbf{5 4 ( 6 7 . 5 )}$ \\
\hline
\end{tabular}

From the result obtained in the table 2, the infection of $S$. haematobium is most distributed in females with $14(17.5 \%)$ than in males with the infected rate of $12(15 \%)$.

\section{DISCUSSION}

In the current study, the occurrence of Schistosoma haematobium in the different selected areas of Bali town showed that the disease is endemic in the town with the prevalence of $26(32.5 \%)$. The result agreed with the findings of Awogun [8], in a study in Kura local government of Kano state, that S. haematobium infection was common in Nigeria.

The prevalence of $S$. haematobium in relation in relation to sex in selected areas of Bali town showed that females $14(17.5 \%)$ were infected more than the male $12(15 \%)$ this was also in line with the work of Ekpo [9] , reported similar findings in Kwara State, Nigeria. In terms of age groups, the study was able to show that the most infected age was between $5-14$ years, this could be linked to their prolonged water contact activities, such as fishing, swimming, farming, among others.

The age profiles also confirmed that infection is most prevalent among school-aged children thus, supporting the need for school based control strategy. The result obtained, there is a noticeable variation in the distribution pattern of the disease, with some having higher prevalence rates than the others among the selected areas of Bali town. This may be related to the availability or otherwise of portable drinking water and the people relative dependence on dry season farming in the area [10].

In Bali Local Government Area, control and prevention of the parasite are in a state of negligence. The role of health education is poor, occupational activity is mainly manual irrigation farming rather than mechanized, and all these were considered as predisposing factors to the disease.

The study showed that previous infection treatment with some orthodox and traditional medicine does not successfully eliminate the disease-burden in the long term due to the continue usage of ineffective drugs for the infection [11].

\section{CONCLUSION}

Based on the result obtained from the study, it is obvious that S. haematobium infection was prevalence in all the three (3) areas of Bali town, Nigeria. Thus, it is a significant milestone towards $S$. haematobium infection control, which would allow easy planning and identification of priority areas, for easy planning and management of the control programme. Therefore, the attention of the State, National and International health authorities as regards the prevention and control measures is thereby urgently needed.

\section{ACKNOWLEDGEMENT}

The authors are grateful to all volunteers in Bali Local Government for their maximum cooperation.

\section{REFERENCES}

[1] Akaje F . Transmission of Schistosoma haematobium in Irrigation Setting. Nigeria. Nigerian Journal of Health Development, 2013; 9(3):147 - 156.

[2] Abbah T, Karanaja DM, Addiss DG . The Comparative Morphology Genital System of Some African Species of Biofilaria; 2010; 32:443 - 450.

[3] Daniel A A, Onu MA, Abubakar, U, Daka DA . Preliminary Studies Schistosomiasis in Zuru Emirate of Kebbi State, Nigeria. The Nigerian Journal Parasitology;2011; $22 \quad$ (182): 65 74.

[4] Ekenjindu IM . Schistosoma haematobium Infection a Reverine Area of Anambra State; Southeastern Nigeria. The Nigeria Journal of Parasitology; 2013;23: 133 - 138.

[5] Ewer, DW ."Ecological Biology” West African Journal of Medicine; 2009; Vol.Part 3:24- 29. 
[6] Frandson OD. "Theodore Maximillian Bilharz, Retrieved on 23 ${ }^{\text {rd }}$ April, 2010; prom a.htt://www.whonamedit.com/doctor.cfc/2829.htm

[7] Glasser, Baligh K. "Renal Disease in Hepatosplenic Schistosoma: A Clinic Pathodological Study" Transaction the Royal Society of Tropical Medicine and Hygiene,2012; 71: 387 - 391.

[8] Awogun, JA . "A Newly Identified Lineage of Schistosoma". International Journal of Parasitology; 2014; 33(9): 977 - 85.

[9] Ekpo, L.M . Biology of parasitic helminthes 6th edition; 2012; 21: 313 - 345.

[10] Robert S. Immunopathology of Schistosoma haematobium Infection. Clinical Microbiology Reviews; 2011; 2(3): 250 - 269.

[11] Ukwubile CA. Anthelminthic studies of some Nigerian medicinal plants in children age 5-12 in Ogurugu, Uzo-Uwani Local Government Areas of Enugu State Nigeria. Bacteriology and Parasitology; 2012, 3(9) Omnics.org 